DOI 10.31558/2519-2949.2018.1.6

УДК 323.22:328.123:328.18

\author{
Кольцов В. М., Дерэсавний заклад «Південноукраӥнський національний \\ педагогічний університет імені К. Д. Уиинського»
}

\title{
СУТНІСТЬ, ОСОБЛИВОСТІ ТА РІЗНОВИДИ АНТИСИСТЕМНОЇ ПОЛІТИЧНОї ОПОЗИЦї̈
}

\begin{abstract}
Проаналізовано сутність, особливості та різновиди антисистемної політичної опозиції як противаги системній політичній опозиџї. Виявлено, щуо антисистемна політична опозищія може бути парламентською і позапарламентською, напівлояльною і нелояльною, легальною і нелегальною, насильницькою і ненасильницькою, а також може визнаватись або не визнаватись політичним режсимом/владою. Зафіксовано, ще антисистемна політична опозичія детермінується антисистемним типом опозиційних політичних партій, що мають такі цінності, які релящійно й ідеологічно діаметрально протилежні цінностял, ще панують у системі, де існують такі політсили. Водночас вмотивовано, щяо для того, щеб трактуватись антисистемною, політсила не повинна протистояти всім без винятку характеристикам відповідної політичної системи, а хоча би одній із них. Але це, у свою чергу, означає, що ідеологічна антисистемність політсил тежс обов'язково пов'язана із політичною системою, однак з цілком іншою політичною системою і по-іншому згенерованою в умовах релямійної антисистемності. Сумарно ие засвідчує, щзо релящійна антисистемність політсил і політичної опозиції відноситься до порівняльного аналізу партійних систем, а ідеологічна антисистемність політсил і політичної опозиції є важслиим конщептуальним інструментом для аналізу проблем демократії та демократизаиії, а також автократії та автократизаиії. Водночас така генералізачія не є довершеною, адже будучи теоретизованою, вона має перевірятись практикою політичного прочесу, який може вносити додаткові корективи у розуміння сутності антисистемної політичної опозиції.
\end{abstract}

Ключові слова: опозиція, антисистемна опозиція, антисистемна політична сила, ідеологічна антисистемність, реляційна антисистемність.

Поряд 3 визначальним впливом системної політичної, зокрема парламентської, опозиції на структуризацію політичного процесу і консолідацію/деконсолідацію сучасних демократій та автократій, доволі вагоме значення має апелювання й до феномену антисистемної політичної опозиції. Це корелює зі звиклим зауваженням Х. Лінца про те, що політична опозиція на підставі врахування реалізовуваних нею засобів політичної боротьби і ставлення до реального чи можливого застосування насильства у різних типах режимів повинна бути поділена на лояльну чи системну, напівлояльну чи напівсистемну та нелояльну чи антисистемну [11, с. 27-38]. Навіть не дивлячись на те, що в тому або іншому кейсі політичного режиму може бути створене цілком самодостатнє інституційне середовища конструктивізації політичної (передусім парламентської) опозиції. Річ у тому, що навіть задекларований та інституціоналізований, не кажучи про незадекларований i неінституціоналізований, консенсус стосовно «правил гри» не убезпечує ту чи іншу політію усестороннім та максимально надійним механізмом «відторгнення впливу» й популярності екстремістсько/радикально налаштованих організацій, які різною мірою становлять феномен антисистемної опозиції. Відтак запропоноване дослідження актуалізоване потребою політологічного аналізу сутності, особливостей і різновидів антисистемної політичної опозиції як противаги системній, зокрема парламентській, опозиції.

Заявлена проблематика знайшла відображення у наукових доробках таких вчених, як І. Большаков [1], Н. Вінничук [2], Х. Даалдер [8; 9], М. Зуліанелло [17], Г. Іонеску та I. де Мадаріага [10], Дж. Капочіа [6], Х. Лінц [11], Р. Макрідіс [12], Р. Паннет [13], О. Попова [3], Дж. Сарторі [1416], А. Хіршман [4], А. Циганков [5] й інші. Однак у них так і не вироблено синтетичного бачення 3 приводу сутності й особливостей антисистемної політичної опозиції. Відтак метою статті $\epsilon$ виявлення і систематизація особливостей та різновидів антисистемної політичної опозиції, зокрема на підставі iї варіативного дефініювання і структуризації.

Приступаючи до розв'язання поставленої мети, наголошуємо, що розгляд наукової літератури засвідчує, що сьогодні у практиці різних країн світу, політичні режими яких тяжіють чи до демократії, чи до автократії, є всі підстави для дихотомії між: а) системною (зазвичай, однак 
не завжди парламентською) опозицією, яка часто синонімізується як відповідальна, законна, класична, конституційна, легальна, лояльна, нормальна, реальна, регулярна, i така, що функціонує «спокійно та конструктивно», виступаючи «проти» влади, але не перешкоджаючи владі, і відповідно окреслюється здебільшого у рамках вузького чи інституційного підходу до дефініювання опозиції; б) антисистемною (зазвичай, але не завжди позапарламентською) опозицією, яка синонімізується категоріями антиорганізаційної, девіантної, екстремістської, невідповідальної, незаконної, нелегальної/напівлегальної, нелояльної/напівлояльної, ненормальної, протидіючої тощо та позиціонується як така, що ставить під сумнів легітимність політичного режиму в цілому і діє безвідповідально, бо не має жодних шансів бути репрезентованою при владі, й відповідно окреслюється здебільшого у рамках широкого чи соціологічного підходу до дефініювання опозиції [15, с. 151].

Водночас, наукова література детермінує, що є всі умови для поглиблення та диверсифікації знань про антисистемну політичну опозицію, адже вона може як визнаватись, так і не визнаватись політичним режимом та владою (передусім урядом, коли йдеться про демократичні країни, або будь-яким автократичним центром, коли йдеться про недемократичні країни). Причому, як вказує Дж. Капочіа [6, с. 16], коли уряд толерує чи не заперечує антисистемну політичну опозицію, він розуміє, що вона $є$ маргінальною та не має істотного потенціалу реалізації своїх цілей та ідеології чи що в іiі існуванні і діяльності простежується відмінність між іiі ідеологією й очікуваними результатами їі діяльності. І навпаки, коли уряд відчуває загрозу зі сторони антисистемної опозиції, то він всіляко намагається маргіналізувати іiі та протистояти будь-якому резервному потенціалу іiі політичного впливу.

А тому, як вказують деякі вчені $[2 ; 5 ; 11$, с. 27-38], антисистемна опозиція може бути як парламентською, так і позапарламентською, особливо коли йдеться про країни, політичні режими яких $є$ демократичними. Це унаслідувано у тому факті, що антисистемну політичну опозицію доцільно структуризувати на напівлояльну (яка звикло $\epsilon$ парламентською чи може стати парламентською) і нелояльну (яка традиційно не має, а інколи і не може мати парламентського представництва). Причому напівлояльна політична опозиція виступає проти радикальної трансформації або руйнації чинної політичної системи, хоча, не маючи чітко визначеної позиції (вона коливається від неприйняття існуючого політичного режиму і прагнення його змінити до згоди 3 основними стратегічними парадигмами політичного режиму, але за наявності незгод тактичного характеру може комбінуватись на підставі співпраці непримиренних та поміркованих опозиційних партій і рухів), може і організовувати акції проти уряду, і підтримувати дії нелояльної політичної опозиції, не беручи у них участі. Натомість нелояльна політична опозиція - це опозиція, за якої основна частина опозиційних партій і рухів чітко та недвозначно заперечує чинну політичну систему, на підставі чого політичний режим схиляється до змін, а політична влада поступово втрачає легітимність, адже не здатна чинити опір непримиренній опозиційності.

Сумарно це доводить, що коли напівлояльна політична опозиція є легальною, тоді вона таксономується як антисистемна політична опозиція у рамках політичної системи (що буває не дуже часто). А натомість коли нелояльна політична опозиція $є$ нелегальною, тоді вона позиціонується як антисистемна опозиція поза рамками політичної системи (що трапляється частіше) [10, с. 128]. Це здебільшого відповідає дихотомії антисистемної політичної опозиції на насильницьку (революційну, радикальну), яка звикло не інституціоналізована й не формалізована у політичній системі, та ненасильницьку (нереволюційну, реформаторську), яка має легальне право виконувати свою роль у політичній системі, а тому ії «лояльність» доволі часто є марною спробою домогтись фундаментальних змін [12, с. $166 ; 13$, с. 30$]$.

Також загальнотеоретично цілком очевидно, що «входження» опозиції у політичну систему має два різні зрізи: формальний - наявність офіційної реєстрації в якості партії чи руху і представництво у структурах влади; неформальний - контакти 3 представниками правлячої еліти без офіційної реєстрації у якості партії чи руху. А відтак всі інші опозиційні структури у політичну систему «не включаються» через відсутність окреслених вище характеристик, а тому й з великою часткою ймовірності становлять феномен антисистемної опозиції [1, с. 109]. Остання, у свою чергу і відповідно, характеризується використанням переважно неконвенціональних методів політичної боротьби, слабкістю політичних ресурсів, «віртуалізацією» політичної активності, зазвичай (особливо в умовах демократичного режиму) низькою кількістю прихильників, низькою довірою 3 боку громадян, а тому і невписаністю у систему представництва інтересів та неможливістю участі у виробленні політичних рішень [3]. 
Це здебільшого, у тому числі в умовах демократії та автократії, відповідає зауваженню й концепту Дж. Сарторі, згідно із яким антисистемна політична опозиція детермінується особливим (антисистемним) типом опозиційних політичних партій, що мають цінності й ідеологію, діаметрально протилежні цінностям й ідеології, які панують у системі, в котрій існують політсили [16, с. 116-118]. Причому у вузькому розумінні антисистемна партія/політсила у такому зрізі є політсилою, яка дотримується «тієї системи переконань, що не поділяє цінностей політичного ладу, в рамках якого вона існує». А відтак вона цілеспрямована, будучи «принциповою опозицією» [16, с. 133], не тільки на зміну виконавчої влади, а й на зміну системи організації державної влади загалом, у рамках якої діє уряд [16, с. 132-133]. Натомість у широкому сенсі антисистемна партія є політсилою, яка намагається i спроможна підірвати легітимність режиму, якому вона опонує [17], вживаючи для цього різні неконвенціональні засоби політичної боротьби - «від відчуження до протесту» [16, с. 132$].$

Відтак, головна відмінність антисистемної політичної опозиції від системної політичної опозиції не у радикальності методів політичної боротьби, а в наявності максимальної ідеологічної дистанції [1, с. 109]. Інкорпоровано це у тому факті, що антисистемні партії традиційно $\epsilon$ політсилами, які займають місце, віддалене від політичного й партійно-ідеологічного центру, визначеного у політико-конституційному вимірі тієї чи іншої країни [16, с. 154, 163]. Саме тому, згідно 3 теорією партійних систем, розмірність «партійної антисистемності» - це ідеологічна відстань однієї партії (антисистемної) від інших партій (системних) відносно тих питань, які мають вирішальне значення для політичної системи, у якій ці партії функціонують.

У демократичних, а інколи й автократичних режимах це звикло виявляється у функціонуванні так званих екстремістських/радикальних лівих (анархістських та комуністичних) i екстремістських/радикальних правих й нацистських/неонацистських) партій та рухів [17]. Навіть попри те, що вони не обов'язково мають революційний характер, адже антисистемність може виявлятися у діапазоні від простого неприйняття до відкритого протесту супроти політичної системи. Однак з обов'язковим наголосом на тому, що антисистемна політсила (партія чи рух) трактується як загроза тому чи іншому типу політичного режиму $[6$, с. $10 ; 10]$.

Це, у випадку найперше демократичного політичного режиму, відповідає чи не первинному розумінню феномену антисистемної партії, запропонованому Х. Даалдером, за яким антисистемні партії «беруть участь у знищенні» демократій [9, с. 64]. Крім того, це значною мірою корелює 3 вказівками інших вчених про доцільність виокремлення таких феноменів, як «основна структурна опозиція» (Р. Даль), «принципова опозиція» (О. Кіркхаймер), «нелояльна опозиція» (Х. Лінц), «партія чи група $з$ недемократичними ідеалами» (Х. Даалдер, Я. Бадж і В. Херман, К. фон Бейме), «партія або група 3 неконвенціональною, незаконною чи насильницькою поведінкою» (Е. Ціммерман), «ізольована опозиція» (Л. Білл, П. Пульцер).

А відтак це засвідчує, що концептуальна логіка Дж. Сарторі спрямована на подвійне засвідчення саме реляційної антисистемності партій: із однієї сторони, його концепція передбачає ідеологічну дистанційованість антисистемної партії від інших (системних) партій у політичному (ліво-правому) просторі електоральної конкуренції; із другої сторони, його концепція стосується делегітимізуючого впливу дій та пропаганди антисистемної партії на політичний режим, у якому вона функціонує. Відповідно підхід Дж. Сарторі зазвичай не засвідчує об'єктивного змісту ідеологій антисистемних партій як таких, а натомість лише означує відношення ідеології антисистемних партій до основоположних цінностей певних типів політичного режиму і партійної системи [6, с. 9].

Дещо видозміненої позиції (на відміну від надто ідіосинкратичного, реляційного і «розтягнутого» підходу Дж. Сарторі [6, с. 9; 7]) дотримується Дж. Капочіа, який зауважує, що на противагу системності опозиції як уніфікованій категорії більш доречно говорити не лише про антисистемність опозиції та іï окремі виміри, а й про несистемність і позасистемність опозиції [6, c.9]. У такому випадку позасистемність і несистемність політичної опозиції означає, що вона опонує політичній системі або якійсь окремій ¥іi складовій, зокрема системі влади, державній системі, системі суспільних або ж міжінституційних відносин тощо [1, с. 110]. Причому опозиція здебільшого є позасистемною, коли вона перебуває за рамками політичної системи і ніяк 3 нею не взаємодіє, будучи таким чином структурою, яка існує поза політичним життям та ніяк 3 ним не стикається (що наближує позасистемність до абсентеїзму та неучасті у політиці). Натомість несистемна політична опозиція звикло окреслюється категорією незареєстрованих/неофіційних та непарламентських політичних сил, які опозиційно (часто у формі відкритого протесту, спрямованого або на руйнування і подальшу реконструкцію політичної системи (революційно), або 
на її зміну і поступовий «капітальний ремонт» $[1 ; 4]$ (еволюційно)) ставляться до політичної системи у цілому і до їі інститутів зокрема.

У поданні Дж. Капочіі це означає, що антисистемність партії та політичної опозиції варто трактувати дихотомічно - реляційно й ідеологічно [6, с. 10; 17]. Але не обов'язково споріднено і паралельно, хоча б зважаючи на iї теоретико-методологічну окресленість/зумовленість партологічними теоріями і теоріями демократії та автократії. У партологічному сенсі (в контексті партійних систем) критерієм антисистемності $є$ реляційність, тобто властивість політсили (партії чи руху) зумовлювати поляризацію i відцентрову механіку партійної системи. Натомість у демократизаційному сенсі (чи в континуумі «демократія - автократія») критерієм антисистемності $\epsilon$ ідеологічність, тобто здатність політсили протистояти ознакам демократичного або автократичного режиму [6, с. 22-23]. Дихотомує ці дві стратегії дефініювання антисистемних партій те, що на відміну від реляційної антисистемності партій і їхніх системних наслідків, які краще оцінювати ретроспективно, ідеологічна антисистемність партій може бути оцінена лише шляхом спекуляцій стосовно майбутніх намірів партій. Інакше кажучи, майбутні (ex post) наслідки антисистемної позиції політсил постулюються на підставі чинної (ex ante) оцінки їхньої антисистемності [6, с. 9].

Натомість об'єднують ці дві стратегії дефініювання антисистемних партій, а відтак i антисистемної опозиції, їхні ключові атрибути й ознаки: 1) віддалене ідеологічно-просторове розташування виборців антисистемних партій від виборців «сусідніх» партій мейнстрімного характеру (які конструктивізують відносини влади й опозиції); 2) низький потенціал коаліційності антисистемних політсил; 3) тактика надмірної делегітимізації та пропагандизації політичного процесу антисистемними партіями; 4) нерівномірна ідеологічна дистанція між системними й антисистемними партіями; 5) відцентровість і надмірна поляризація (багатополярність у кластері «ліві - центр - праві») політичного процесу й міжпартійної конкуренції $[6$, с. 9; 14]. На цьому тлі антисистемні політсили, які виключаються з парламентських/урядових коаліцій і позиціонуються як політично «безвідповідальні» [16, с. 139-140] й ідеологічно опозиційні політичному режиму, у якому вони функціонують, максимізують політичну поляризацію й ідеологічну дистанцію [8, с. 99, 103], підривають доцентрові тенденції міжпартійної конкуренції, а натомість розвивають потенційно «винагороджувальну» для себе тактику, яка полягає у делегітимізації політичної системи і «спотворенні політичного ринку» [6, с. 9].

Сумарно це означає, що якщо політсила (партія або рух) зазнає змін у своїх коаліційних чи пропагандистських стратегіях, то вона перестає володіти властивістю антисистемності. I навпаки, політсила залишається антисистемною, якщо вона «нелояльна коаліційно» [6, с. 26] і нездатна до пактування. Доповнюється це ідеєю М. Зуліанелло [17], який зазначає, що антисистемною $є$ політсила (партія чи рух), у випадку якої одночасно виконуються дві вимоги: а) ідеологічне позиціонування політсили щодо політичного статусу-кво не просто призводить до артикуляції звиклого несприйняття влади/уряду й оформлення політико-орієнтованої опозиції ій/йому, але i зумовлює генерування питань метаполітичного характеру, зокрема щодо доцільності та раціональності чинної політичної системи і ії політичних інститутів; б) політсила не бере участі у помітних кооперативних взаємодіях на системному рівні, навіть не зважаючи на власне антагоністичне самосприйняття та/або ставлення інших партій у системі, а тому виступає за радикальне анулювання й зміну/заміну чинної партійної системи. Відтак, в умовах, приміром, демократичних політичних режимів позначення політсил як ідеологічно антисистемних $є$ очевидним синонімом їхнього позначення як антидемократичних [6]. Більше того, ідеологічна антисистемність політсил за своєю природою є «негативним явищем», адже окреслює протидію таких політсил певним об'єктам політичного процесу.

Узагальнюючи таку логіку, засвідчуємо, що для того, щоби трактуватись антисистемною, політична сила (партія чи рух) не повинна протистояти всім без винятку характеристикам відповідної політичної системи, а хоча би одній із них. Але це, у свою чергу, означає, що ідеологічна антисистемність політсил теж обов'язково пов'язана із політичною системою, однак з цілком іншою політичною системою i по-іншому згенерованою в умовах реляційної антисистемності. Сумарно це засвідчує, що реляційна антисистемність політсил і політичної опозиції відноситься до порівняльного аналізу партійних систем, а ідеологічна антисистемність політсил і політичної опозиції $є$ важливим концептуальним інструментом для аналізу проблем демократії та демократизації, а також автократії та автократизації. Водночас така генералізація не $\epsilon$ довершеною, адже будучи теоретизованою, вона має перевірятись практикою політичного процесу, який може вносити додаткові корективи у розуміння сутності антисистемної політичної опозиції. 


\section{Бібліографічний список:}

1. Большаков И. Несистемная оппозиция : Терминологическая «ошибка» или политическая реальность? / Иван Большаков // Свободная мысль. - 2011. - № 3 (1622). - С. 109-118.

2. Вінничук Н. Типологія політичної опозиції / Наталія Вінничук // Політичний менеджмент. - 2007. № 3. - С. 51-59.

3. Попова О. Политика современного российского государства в отношении несистемной оппозиции

/ О. В. Попова. - М., 2010. - С. 98-103.

4. Хиршман А. Выход, голос и верность : Реакция на упадок фирм, организаций и государств

/ А. Хиршман. - М., 2009. - 153 с.

5. Цыганков А. Современные политические режимы : структура, типология, динамика / А. Цыганков. М. : Интерпакс, 1995. - 320 с.

6. Cappocia G. Anti-System Parties : A Conceptual Reassessment / Giovanni Cappocia // Journal of Theoretical Politics. - 2002. - Vol. 14. - No. 1. - P. 9-35.

7. Collier D. Conceptual «Stretching» Revisited : Adapting Categories in Comparative Analysis / David Collier, James E. Mahon // American Political Science Review. - 1993. - Vol. 87. - P. 845-855.

8. Daalder H. In Search for the Center of European Party Systems / Hans Daalder // American Political Science Review. - 1984. - Vol. 78. - P. 92-109.

9. Daalder H. The Netherlands : Opposition in a Segmented Society / Hans Daalder // Dahl R. Political Oppositions in Western Democracies / Robert A. Dahl. - New Haven, CT and London : Yale University Press, 1966. - P. 188-236.

10. Ionescu G. Opposition : Past and Present of a Political Institution / Ghiţa Ionescu, Isabel de Madariaga. London : The New Thinker Library, 1968. - 213 p.

11. Linz J. Crisis, Breakdown and Reequilibration / Linz Juan J. // Linz J. The Breakdown of Democratic Regimes / Juan J. Linz, Alfred Stepan. - Baltimore, London : Johns Hopkins University Press, 1978. - P. 3 -124.

12. Macridis R. Oppositions in France : An Interpretation / Roy C. Macridis // Government and Opposition..1972. - Vol. 7. - No. 2. - P. 166-185.

13. Punnet R. Front-Bench Opposition : The Role of Leader of the Opposition, the Shadow Cabinet and Shadow Government in British Politics / Robert Malcolm Punnett. - Heinemann, 1973. - 500 p.

14. Sani G. Polarization, Fragmentation and Competition in Western Democracies / Giacomo Sani, Giovanni Sartori // Daalder H. Western European party systems : Continuity and Change / Hans Daalder, Peter Mair. - Beverly Hills, CA : Sage, 1983. - P. 307-340.

15. Sartori G. Opposition and Control Problems and Prospects / Giovanni Sartori // Government and Opposition. - 1966. - Vol. 1. - No. 2. - P. 149-154.

16. Sartori G. Parties and Party Systems : A Framework for Analysis / Giovanni Sartori. - Cambridge : Cambridge University Press, 1976. - 342 p.

17. Zulianello M. Anti-System Parties Revisited : Concept Formation and Guidelines for Empirical Research / Mattia Zulianello // Government and Opposition. - 2017. - Published online [10 May 2017]. - 29 p.

\section{Kolzov V. M. The essence, features and types of anti-system political opposition}

The article is dedicated to analysing the essence, features and varieties of anti-system political opposition as a counter-weight to systemic political opposition. The author discovered that anti-system political opposition can be parliamentary and extra-parliamentary, semi-loyal and disloyal, legal and illegal, violent and non-violent, and also can be recognized or not recognized by a political regime/government. It was also recorded that anti-system political opposition is determined by the antisystem type of oppositional political parties, which have such values that are relationally and ideologically opposed to the values prevailing in the system, where such political parties exist. At the same time, it was motivated that political party, in order to be interpreted as anti-system, should not resist all (without exception) the characteristics of the corresponding political system, but at least one of them. But this, in turn, means that the ideological antisystem of political power is also necessarily linked to the political system, but with a completely different political system and differently generated in the context of relational antisystemism. In total, this indicates that the relational anti-system of political forces and political opposition refers to the comparative analysis of party systems, while the ideological antisystem of political forces and political opposition is an important conceptual tool for analyzing the problems of democracy and democratization, as well as autocracy and autocratization. At the same time, such a generalization is not perfect, as being theoreticized, it should be checked by the practice of the political process, which may make additional adjustments to the understanding of the essence of the antisystem political opposition.

Key words: opposition, anti-system opposition, anti-system political party, ideological anti-system, relational anti-system. 